Carbon Dioxide Complexes

DOI: 10.1002/anie.200502400

\section{Aluminum-Magnesium Complexes with Linearly Bridging Carbon Dioxide ${ }^{* *}$}

Chung-Cheng Chang,* Min-Chun Liao, Tsu-

Hsin Chang, Shie-Ming Peng, and Gene-Hsiang Lee

Earlier, we found that an oxygen atom of carbon dioxide bonds to a metal atom when carbon dioxide is fixed by the $\mathrm{Al}-$ $\mathrm{Mg}$ mixed-metal compounds $\left[\mathrm{Me}_{2} \mathrm{Al}\left(\mu-\mathrm{NR}_{2}\right)_{2} \mathrm{Mg}(\mu-\mathrm{Me})\right]_{n}$ $(\mathrm{R}=i \operatorname{Pr}, n=4 ; \mathrm{R}=\mathrm{Et}, n=2)$. Subsequently, the amino leaving group migrates from the attacked metal atom to the carbon atom of the carbon dioxide to form $\mathrm{Al}-\mathrm{Mg}$ carbamato complexes. ${ }^{[1]}$ The $\mathrm{CO}_{2}$-ligated $\mathrm{Mg}$ compounds show a variety of bonding modes ${ }^{[2]}$ However, to date the linear $\mu\left(\mathrm{O}, \mathrm{O}^{\prime}\right)-\mathrm{CO}_{2}$ coordination mode of carbon dioxide has not been observed, either in main group or in transition metal compounds. ${ }^{[3]}$

In accordance with earlier work by Sita et al., ${ }^{[4]}$ we presume that the reaction of $\mathrm{Mg}\left[\mathrm{N}\left(\mathrm{SiMe}_{3}\right)_{2}\right]_{2}$ with carbon dioxide could also generate an oxo-transfer product, namely, $\mathrm{Mg}\left(\mathrm{N}\left(\mathrm{SiMe}_{3}\right)_{2}\right)\left(\mathrm{OSiMe}_{3}\right)$, and the expected $\mathrm{O}=\mathrm{C}=\mathrm{N}\left(\mathrm{SiMe}_{3}\right)$, instead of generating a carbamato complex. ${ }^{[5]}$ In light of our previous experience with trialkylaluminum reagents and taking advantage of the oxo-transfer compound $\mathrm{Mg}$ $\left[\mathrm{N}\left(\mathrm{SiMe}_{3}\right)_{2}\right]\left(\mathrm{OSiMe}_{3}\right)$, we proposed a process for studying $\mathrm{CO}_{2}$ fixation in a mixture of $\mathrm{Mg}\left[\mathrm{N}\left(\mathrm{SiMe}_{3}\right)_{2}\right]_{2}$ and trialkylaluminum.

[*] Prof. Dr. C.-C. Chang, M.-C. Liao, Prof. Dr. T.-H. Chang

Department of Chemistry

National Sun Yat-Sen University

Kaohsiung, 804 (Taiwan)

Fax: (+ 886) 7525-2009

E-mail: ccccc@mail.nsysu.edu.tw

Prof. Dr. S.-M. Peng, G.-H. Lee

Department of Chemistry

National Taiwan University

Taipei, 117 (Taiwan)

[**: This work was supported by the National Science Council of Taiwan (NSC 93-2113M-110-005 to C.C.C.). We are greatly indebted to Analytische Laboratorien Prof. Dr. H. Malissa und G. Reuter GmbH (Germany) for elemental analysis, and to Prof. Dr. Michael Y. Chiang at the National Sun Yat-Sen University for constructive discussions.

Supporting information for this article is available on the WWWW under http://www.angewandte.org or from the author.
One equivalent of $\mathrm{AlR}_{3}(\mathrm{R}=\mathrm{Me}, \mathrm{Et})$ was added to a solution of $\mathrm{Mg}\left[\mathrm{N}\left(\mathrm{SiMe}_{3}\right)_{2}\right]_{2}$ in $\mathrm{THF}$ at room temperature, and an excess of carbon dioxide was bubbled through the stirred, ice-cooled mixture to yield compounds $\mathbf{1}(\mathrm{R}=\mathrm{Me})$ and $\mathbf{2}(\mathrm{R}=$ Et) [Eq. (1), Scheme 1].

$$
\begin{aligned}
& \mathrm{Mg}\left[\mathrm{N}\left(\mathrm{SiMe}_{3}\right)_{2}\right]_{2}+\mathrm{AlR}_{3}+\mathrm{CO}_{2} \frac{\mathrm{THF}}{0^{\circ} \mathrm{C}} \\
& \quad\left[\left\{\mathrm{R}_{2} \mathrm{Al}\left(\mu-\mathrm{NSiMe}_{3}\right)\left(\mu-\mathrm{OSiMe}_{3}\right) \mathrm{Mg}(\text { thf })_{2}\left(\mu-\mathrm{O}_{2} \mathrm{C}\right)\right\}_{3}\right](\mathbf{1}, \mathbf{2})
\end{aligned}
$$

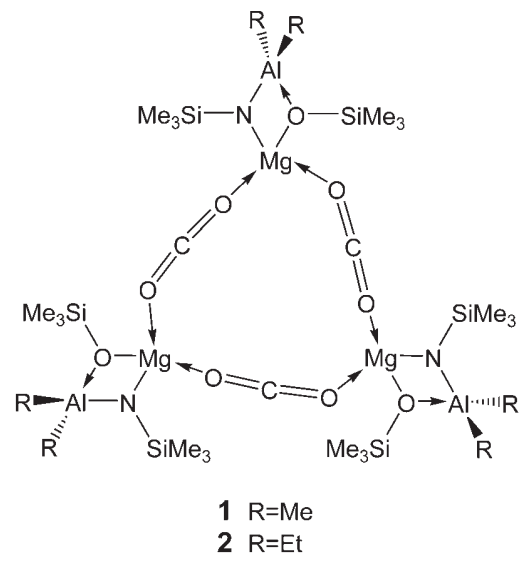

Scheme 1. Schematic representation of 1 and 2. Coordinated THF omitted for clarity.

Presumably, carbon dioxide reacted with $\mathrm{Mg}\left[\mathrm{N}\left(\mathrm{SiMe}_{3}\right)_{2}\right]_{2}$ to give oxo-transfer product $\mathrm{Mg}\left[\mathrm{N}\left(\mathrm{SiMe}_{3}\right)_{2}\right]\left(\mathrm{OSiMe}_{3}\right)$, which is assumed to form a bridged $\mathrm{Al}-\mathrm{Mg}$ intermediate with $\mathrm{AlR}_{3}$ $(\mathrm{R}=\mathrm{Me}, \mathrm{Et})$; this subsequently loses a ligand from the magnesium center and is attacked by a second molecule of carbon dioxide with the oxygen atom as a weak electron donor (Scheme 2). Finally, the carbon dioxide acts as a

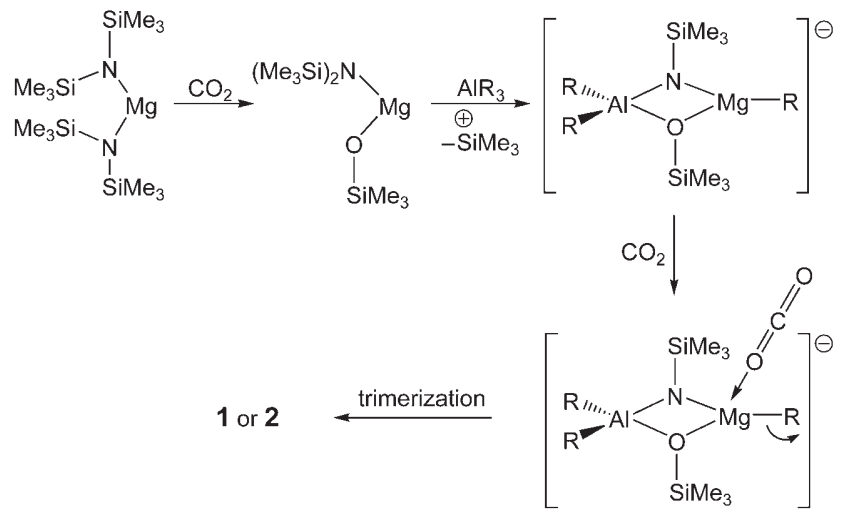

Scheme 2. Proposed reaction path for the formation of $\mathbf{1}$ and $\mathbf{2 .}$

bridging ligand to form a trimer. The products were characterized by elemental analysis, FTIR spectroscopy, and X-ray analysis. The single-crystal X-ray diffraction data confirmed the molecular structures (Figures 1 and 2) ${ }^{[6]}$ The skeletons of 1 and $\mathbf{2}$ have a $C_{3}$ symmetry axis and can be viewed as composed of three equivalent motifs, each of which has a 


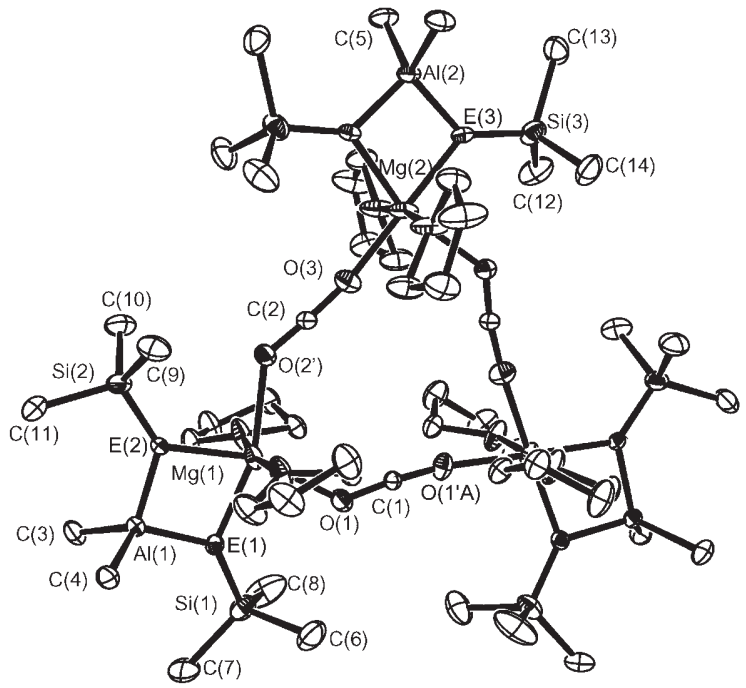

Figure 1. ORTEP view of 1 in the solid state. Thermal ellipsoids are drawn at the $20 \%$ probability level. Selected bond lengths $[\AA \AA]$ and angles [ ${ }^{\circ}$ : $\mathrm{Mg}(1)-\mathrm{O}(1) 2.211(11), \mathrm{Mg}(1)-\mathrm{O}\left(2^{\prime}\right) 2.232(12), \mathrm{Mg}(2)^{-}$ $\mathrm{O}(3)$ 1.944(10), $\mathrm{O}(1)-\mathrm{C}(1) 1.208(10), \mathrm{O}\left(2^{\prime}\right)-\mathrm{C}(2) 1.166(13), \mathrm{O}(3)-$ $C(2) 1.223(10) ; O\left(1^{\prime} A\right)-C(1)-O(1) 173.6(10), O\left(2^{\prime}\right)-C(2)-O(3)$ 175.3(8), $\mathrm{C}(1)-\mathrm{O}(1)-\mathrm{Mg}(1)$ 133.2(6), C(2)-O(2')-Mg(1) 134.1 (6), C(2')-O(3)$\mathrm{Mg}(2)$ 171.1 (8), $\mathrm{E}(1)-\mathrm{Mg}(1)-\mathrm{E}(2)$ 75.53(12) $\mathrm{E}(1)-\mathrm{Mg}(1)-\mathrm{O}(1)$ 85.9(2) $\mathrm{E}(2)-\mathrm{Mg}(1)-\mathrm{O}\left(2^{\prime}\right)$ 86.8(3), $\mathrm{O}(1)-\mathrm{Mg}(1)-\mathrm{O}\left(2^{\prime}\right)$ 111.8(3). Atoms $\mathrm{E}(1)$, $E(2)$, and $E(3)$ were refined as mixed atoms $(50 \% \mathrm{O}$ and $50 \% \mathrm{~N})$.

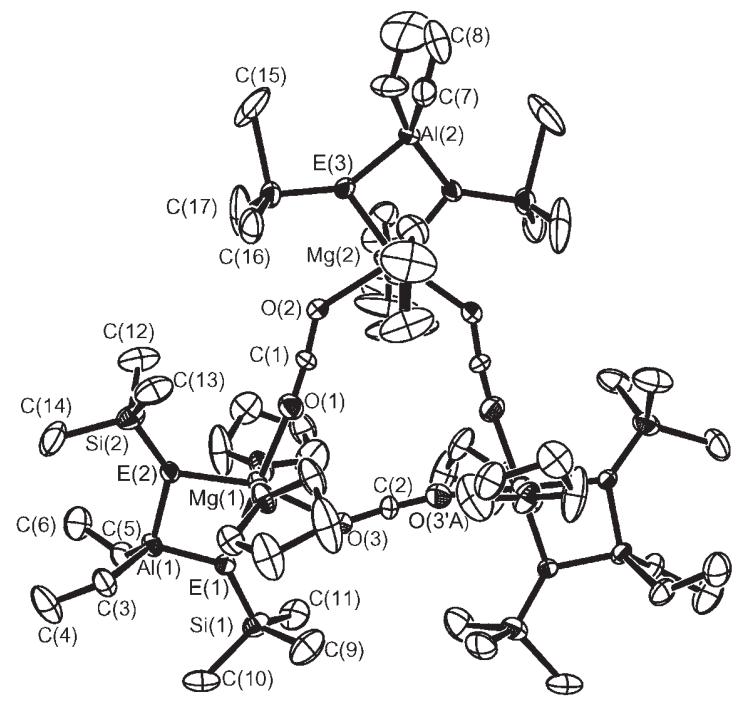

Figure 2. ORTEP view of $\mathbf{2}$ in the solid state. Thermal ellipsoids are drawn at the $20 \%$ probability level. Selected bond lengths $[\AA]$ and angles [ $\left[^{\circ}\right]: \mathrm{Mg}(1)-\mathrm{O}(1) 2.004(16), \mathrm{Mg}(1)-\mathrm{O}(3)$ 2.184(11), $\mathrm{Mg}(2)-\mathrm{O}(2)$ $2.181(10), \mathrm{O}(1)-\mathrm{C}(1) 1.149(15), \mathrm{O}(2)-\mathrm{C}(1) 1.222(11), \mathrm{O}(3)-\mathrm{C}(2)$ $1.201(10)$; O(1)-C(1)-O(2) 173.3(9), O(3'A)-C(2)-O(3) 169.6(10), C(1)$\mathrm{O}(1)-\mathrm{Mg}(1)$ 171.3(11), C(1)-O(2)-Mg(2) 134.9(7), C(2)-O(3)-Mg(1) 136.9(7), O(1)-Mg(1)-E(2) 104.6(4), E(1)-Mg(1)-E(2) 76.03(13), O(1)$\mathrm{Mg}(1)-\mathrm{O}(3)$ 92.3(4), $\mathrm{E}(1)-\mathrm{Mg}(1)-\mathrm{O}(3)$ 86.9(3). Atoms $\mathrm{E}(1), \mathrm{E}(2)$, and $E(3)$ were refined as mixed atoms $(50 \% \mathrm{O}$ and $50 \% \mathrm{~N})$.

bridged $\mathrm{Al}-\mathrm{Mg}$ structure. The six-coordinate magnesium atom is linked to a four-coordinate aluminum atom by bridging $\mathrm{OSiMe}_{3}$ and $\mathrm{NSiMe}_{3}$ groups. Two alkyl groups are retained on each aluminum atom to attain a coordination number of four. The magnesium atoms of the three motifs are joined through three approximately linear carbon dioxide bridges to form a twelve-membered ring.

Atoms $\mathrm{O}(4)-\mathrm{O}(6)$ of $\mathbf{1}$ and $\mathrm{N}(1)-\mathrm{N}(3)$ of $\mathbf{2}$ were refined as mixed atoms $(50 \% \mathrm{O}$ and $50 \% \mathrm{~N})$ due to their disorder in the $\mathrm{OSiMe}_{3}$ and $\mathrm{NSiMe}_{3}$ groups. The requirement for charge balance in the molecule and elemental analysis supported the assignment of these atoms. Compounds $\mathbf{1}$ and $\mathbf{2}$ have very similar skeletons.

In 1 and 2, the $\mathrm{Mg}-\mathrm{O}$ bond lengths of 1.944(10)-2.232(12) and 2.004(16)-2.184(11) $\AA$, respectively, in the $\mathrm{MgCO}_{2}$ moiety are within the range expected for such bonds (Mg $\leftarrow \mathrm{O}$ (monodentate $\mathrm{O}$ donor ligand): 2.012-2.236 $\AA$ ). ${ }^{[7]}$ These bond lengths indicate that each oxygen atom donates a lone pair of electrons to the vacant $\mathrm{p}_{z}$ orbital of the electropositive magnesium atom in a dative bond. In other words, each carbon dioxide molecule links two magnesium atoms in a linear $\mu\left(\mathrm{O}, \mathrm{O}^{\prime}\right)$ bonding mode. The $\mathrm{C}-\mathrm{O}$ bond lengths of 1.166(13)-1.233(10) and 1.149(15)-1.222(11) A, respectively, are very close to that of free carbon dioxide ${ }^{[8]}$ and $\mathrm{Mn}(\mathrm{HCOO})_{3} \cdot{ }^{1} / 2 \mathrm{CO}_{2} \cdot{ }^{1} / 4 \mathrm{HCOOH}^{2} /{ }_{3} \mathrm{H}_{2} \mathrm{O},{ }^{[9]}$ and thus suggest the presence of $\mathrm{C}=\mathrm{O}$ bonds. The $\mathrm{O}-\mathrm{C}-\mathrm{O}$ bond angles of 173.6(10)-175.3(8) and 169.6(10)-173.3(9) ${ }^{\circ}$, respectively, are close to $180^{\circ}$ and suggest sp-hybridized $\mathrm{C}$ atoms. The $\mathrm{Mg} \leftarrow \mathrm{O}=\mathrm{C}=\mathrm{O} \rightarrow \mathrm{Mg}$ moieties show some disorder, with a shape like an hourglass.

The ${ }^{1} \mathrm{H}$ and ${ }^{13} \mathrm{C}$ NMR and IR spectroscopic data and the elemental analysis further characterized $\mathbf{1}$ and $\mathbf{2}^{[10]}$ The ${ }^{13} \mathrm{C}$ NMR spectra of $\mathbf{1}$ and $\mathbf{2}$ show peaks for the carbon atom of $\mathrm{CO}_{2}$ at 120.87 and 120.76 ppm, respectively, shifted slightly upfield relative to free carbon dioxide. ${ }^{[11]}$

The IR spectra provided further strong evidence for the introduction of carbon dioxide into $\mathbf{1}$ and $\mathbf{2}$. Compounds $\mathbf{1}$ and 2 showed strong absorption at 2267 and $2275 \mathrm{~cm}^{-1}$, respectively, originating from stretching vibration of the bridging carbon dioxide. In comparison to free linear carbon dioxide $\left(v_{\text {asym }} 2348 \mathrm{~cm}^{-1}\right)^{[12]}$ and $\mathrm{Mn}(\mathrm{HCOO})_{3} \cdot{ }^{1} / 2 \mathrm{CO}_{2} \cdot{ }^{1} / 4 \mathrm{HCOOH}$. ${ }_{2}^{2} / 3 \mathrm{H}_{2} \mathrm{O},{ }^{[9]}$ the values are only slightly red-shifted. Decreasing $\mathrm{CO}_{2}$ stretching frequency is an accepted measure of increasing negative charge on the $\mathrm{Mg}$ atom. Hence, the coordinated $\mathrm{CO}_{2}$ molecules in $\mathbf{1}$ and $\mathbf{2}$ donate a small amount of electron density to the more electropositive $\mathrm{Mg}$ atoms.

In summary, we have reported a straightforward, one-pot synthetic pathway that leads to novel aluminum-magnesium complexes containing carbon dioxide in the heretoforeunknown linear $\mu\left(\mathrm{O}, \mathrm{O}^{\prime}\right)$ bonding mode. The formation of $\mathbf{1}$ and 2 shows that interesting products can predictably be obtained when $\mathrm{Mg}\left[\mathrm{N}\left(\mathrm{SiMe}_{3}\right)_{2}\right]_{2}$ and $\mathrm{AlR}_{3}(\mathrm{R}=\mathrm{Me}, \mathrm{Et})$ are reacted with carbon dioxide. Investigations of the electronic and steric effects of substituents on the trialkylaluminum on the reaction with $\mathrm{Mg}\left[\mathrm{N}\left(\mathrm{SiMe}_{3}\right)_{2}\right]_{2}$ and carbon dioxide under the same conditions are in progress.

\section{Experimental Section}

All experiments were carried out in an $\mathrm{N}_{2}$-flushed glove bag, in a dry box, or under vacuum by using standard Schlenk techniques. All solvents were distilled and degassed prior to use. All ${ }^{1} \mathrm{H}$ and ${ }^{13} \mathrm{C}$ NMR spectra were measured on a Varian-500 spectrometer. Chemical shifts 
are referenced to $\mathrm{C}_{6} \mathrm{D}_{6}\left({ }^{1} \mathrm{H}, \delta=7.15 \mathrm{ppm} ;{ }^{13} \mathrm{C}\left\{{ }^{1} \mathrm{H}\right\}, \delta=128.00 \mathrm{ppm}\right)$ FTIR spectra were obtained with a Bio-Rad model FTS-155 FTIR spectrometer.

1: $\mathrm{AlMe}_{3}(2.0 \mathrm{M}$ in toluene, $12 \mathrm{~mL}, 2.38 \mathrm{mmol})$ was added to a solution of $\mathrm{Mg}\left[\mathrm{N}\left(\mathrm{SiMe}_{3}\right)_{2}\right]_{2}(8.21 \mathrm{~g}, 2.38 \mathrm{mmol})$ in THF $(60 \mathrm{~mL})$. The mixture was cooled in an ice bath, and an excess of carbon dioxide was bubbled through the stirred mixture for $2 \mathrm{~h}$. An intermediate exothermic reaction ensued. The resultant solution was cooled in a freezer to give crystals of $\mathbf{1}$. The preparation of complex $\mathbf{2}$ was similar to that of complex $\mathbf{1}$.

1: Yield: $20 \%$. M.p. $>112^{\circ} \mathrm{C}$ (decomp). ${ }^{1} \mathrm{H}$ NMR $(500 \mathrm{MHz}$, $\left.\mathrm{C}_{6} \mathrm{D}_{6}\right): \delta=-0.36\left(\mathrm{~s}, 18 \mathrm{H}, \mathrm{AlCH}_{3}\right), 0.34 \mathrm{ppm}\left(\mathrm{m}, 54 \mathrm{H}, \mathrm{NSi}\left(\mathrm{CH}_{3}\right)_{3}\right.$, $\left.\mathrm{OSi}\left(\mathrm{CH}_{3}\right)_{3}\right) \cdot{ }^{13} \mathrm{C}\left\{{ }^{1} \mathrm{H}\right\} \mathrm{NMR}\left(\mathrm{C}_{6} \mathrm{D}_{6}\right): \delta=-5.75\left(\mathrm{AlCH}_{3}\right), 3.24(\mathrm{NSi}-$ $\left.\left(\mathrm{CH}_{3}\right)_{3} ; \mathrm{OSi}\left(\mathrm{CH}_{3}\right)_{3}\right), 120.87 \mathrm{ppm}\left(\mathrm{CO}_{2}\right)$. IR (Nujol): $\tilde{v}=2267(\mathrm{~s})$, 1252(m), 1040(m), 890(s), 841(s) $\mathrm{cm}^{-1}$.

2: Yield: $53 \%$. M.p. $>116{ }^{\circ} \mathrm{C}$ (decomp). ${ }^{1} \mathrm{H}$ NMR $(500 \mathrm{MHz}$, $\left.\mathrm{C}_{6} \mathrm{D}_{6}\right): \delta=0.24\left(\mathrm{q}, 12 \mathrm{H}, \mathrm{AlCH}_{2}\right), 0.35\left(\mathrm{~m}, 54 \mathrm{H}, \mathrm{NSi}\left(\mathrm{CH}_{3}\right)_{3}, \mathrm{OSi}-\right.$ $\left.\left(\mathrm{CH}_{3}\right)_{3}\right), 1.43 \mathrm{ppm}\left(\mathrm{t}, 18 \mathrm{H}, \mathrm{AlCH}_{2} \mathrm{CH}_{3}\right) \cdot{ }^{13} \mathrm{C}\left\{{ }^{1} \mathrm{H}\right\} \mathrm{NMR}\left(\mathrm{C}_{6} \mathrm{D}_{6}\right): \delta=$ $3.12\left(\mathrm{AlCH}_{2}, \mathrm{NSi}\left(\mathrm{CH}_{3}\right)_{3}, \mathrm{OSi}\left(\mathrm{CH}_{3}\right)_{3}\right), 10.42\left(\mathrm{AlCH}_{2} \mathrm{CH}_{3}\right), 120.76 \mathrm{ppm}$ $\left(\mathrm{CO}_{2}\right)$. IR (Nujol): $\tilde{v}=2275(\mathrm{~s}), 1255(\mathrm{~m}), 1041(\mathrm{~m}), 889(\mathrm{~s}), 842(\mathrm{~s}) \mathrm{cm}^{-1}$.

Received: July 11, 2005

Published online: October 25, 2005

Keywords: aluminum $\cdot$ carbon dioxide fixation . coordination modes $\cdot$ magnesium

[1] a) D. Walther, M. Ruben, S. Rau, Coord. Chem. Rev. 1999, 182, 67; b) C. C. Chang, B. Srinivas, M. L. Wu, W. H. Chiang, M. Y. Chiang, C. S. Hsiung, Organometallics 1995, 14, 5150; c) C. C. Chang, M. S. Ameerunisha, Coord. Chem. Rev. 1999, 189, 199.

[2] a) K. C. Yang, C. C. Chang, C. S. Yeh, G. H. Lee, S. M. Peng, Organometallics 2001, 20, 126; b) K. C. Yang, C. C. Chang, C. S. Yeh, G. H. Lee, Y. Wang, Organometallics 2002, 21, 1296.

[3] a) A. Behr, Angew. Chem. 1988, 100, 681; Angew. Chem. Int. Ed. Engl. 1988, 27, 661; b) D. H. Gibson, Chem. Rev. 1996, 96, 2063.

[4] L. R. Sita, J. R. Babcock, R. Xi, J. Am. Chem. Soc. 1996, 118, 10912.

[5] a) M. T. Caudle, J. W. Kampf, Inorg. Chem. 1999, 38, 5474; b) D. B. Dell'Amico, F. Calderazzo, L. Labella, F. Marchetti, G. Pampaloni, Chem. Rev. 2003, 103, 3857; c) Y. Tang, L. N. Zakharov, A. L. Rheingold, R. A. Kemp, Organometallics 2004, 23, 4788; d) D. B. Dell'Amico, F. Calderazzo, U. Englert, L. Labella, F. Marchetti, M. Specos, Eur. J. Inorg. Chem. 2004 3938; e) E. García-España, P. Gaviña, J. Latorre, C. Soriano, B. Verdejo, J. Am. Chem. Soc. 2004, 126, 5082; f) Y. Tang, W. S. Kassel, L. N. Zakharov, A. L. Rheingold, R. A. Kemp, Inorg. Chem. 2005, 44, 359.

[6] Crystal data for 1.2THF: $\mathrm{C}_{59} \mathrm{H}_{136} \mathrm{Al}_{3} \mathrm{Mg}_{3} \mathrm{~N}_{3} \mathrm{O}_{17} \mathrm{Si}_{6}, M_{\mathrm{r}}=1482.12$, orthorhombic, space group Pbcn, $a=12.4718(6), \quad b=$ 25.4146(11), $c=28.0272(12) \AA, V=8883.7(7) \AA^{3}, Z=4, \rho_{\text {calcd }}=$ $1.108 \mathrm{~g} \mathrm{~cm}^{-3}, \mu=0.199 \mathrm{~mm}^{-1}, \lambda=0.71073 \AA$, transmission range $0.9520-0.9247$, crystal size $0.40 \times 0.40 \times 0.25 \mathrm{~mm}^{3}$. A total of 29148 unique reflections were collected on a Nonius KappaCCD diffractometer at $150 \mathrm{~K}$ in the $\theta$ range $1.45-25.00^{\circ}$. Full-matrix least-squares refinement on $F^{2}$ converged to $R 1=0.1225$ (all data), $0.0783(I>2 \sigma(I)) ; w R 2=0.2401$ (all data), $0.2011(I>$ $2 \sigma(I))$. Atoms $\mathrm{O}(1), \mathrm{O}(2), \mathrm{O}(3), \mathrm{C}(18), \mathrm{C}(22), \mathrm{C}(23), \mathrm{O}\left(1^{\prime}\right)$, $\mathrm{O}\left(2^{\prime}\right), \mathrm{O}\left(3^{\prime}\right), \mathrm{C}\left(18^{\prime}\right), \mathrm{C}\left(22^{\prime}\right)$ and $\mathrm{C}\left(23^{\prime}\right)$ all had half occupancies. Crystal data for 2.THF: $\mathrm{C}_{61} \mathrm{H}_{140} \mathrm{Al}_{3} \mathrm{Mg}_{3} \mathrm{~N}_{3} \mathrm{O}_{16} \mathrm{Si}_{6}, M_{\mathrm{r}}=1494.17$, monoclinic, space group $C 2 / c, a=30.5742(6), b=17.5555(3), c=$ 21.1478(4) $\AA, \beta=127.6215(9)^{\circ}, V=8990.7(3) \AA^{3}, Z=4, \rho_{\text {calcd }}=$ $1.104 \mathrm{~g} \mathrm{~cm}^{-3}, \mu=0.196 \mathrm{~mm}^{-1}, \lambda=0.71073 \AA$, transmission range $0.963-0.883$, crystal size $0.25 \times 0.25 \times 0.22 \mathrm{~mm}^{3}$. A total of 52985 unique reflections were collected on a Nonius KappaCCD diffractometer at $150 \mathrm{~K}$ in the $\theta$ range $1.43-25.00^{\circ}$. Full-matrix least-squares refinement on $F^{2}$ converged to $R 1=0.1423$ (all data), $0.1006(I>2 \sigma(I)) ; w R 2=0.3135$ (all data), 0.2731 ( $I>$ $2 \sigma(I))$. One molecule of THF was disordered. Atoms $\mathrm{Al}(2)$, $\mathrm{Si}(3), \operatorname{Si}\left(3^{\prime}\right), \mathrm{C}(7), \mathrm{C}(8), \mathrm{C}\left(7^{\prime}\right), \mathrm{C}\left(8^{\prime}\right), \mathrm{O}(7), \mathrm{C}(30)$, and $\mathrm{C}(32)$ all had half occupancies. All calculations were performed with the SHELXTL-97 package. CCDC-277386 (1) and -277385 (2) contain the supplementary crystallographic data for this paper. These data can be obtained free of charge from the Cambridge Crystallographic Data Centre via www.ccdc.cam.ac.uk/data request/cif.

[7] C. E. Holloway, M. Melnik, J. Organomet. Chem. 1994, 465, 1.

[8] a) K. K. Pandey, Coord. Chem. Rev. 1995, 140, 37; b) X. Yin, J. R. Moss, Coord. Chem. Rev. 1999, 181, 27.

[9] A. Cornia, A. Caneschi, P. Dapporto, A. C. Fabretti, D. Gatteschi, W. Malavasi, C. Sangregorio, R. Sessoli, Angew. Chem. 1999, 111, 1897; Angew. Chem. Int. Ed. 1999, 38, 1780.

[10] Elemental analysis (\%) calcd for $\mathbf{1}\left(\mathrm{C}_{51} \mathrm{H}_{120} \mathrm{Al}_{3} \mathrm{Mg}_{3} \mathrm{~N}_{3} \mathrm{O}_{15} \mathrm{Si}_{6}\right)$ : C 45.84, H 9.05, N 3.14, Mg 5.45; found: C 45.39, H 8.83, N 3.21, $\mathrm{Mg}, 5.31$. Deviations from calculated values are attributed to the extremely air sensitive and hygroscopic nature of this compound.

[11] a) N. E. Schlörer, S. Berger, Organometallics 2001, 20, 1703; b) C. S. McCowan, T. L. Groy, M. T. Caudle, Inorg. Chem. 2002, $41,1120$.

[12] A. K. Brisdon, Inorganic Spectroscopic Methods, Oxford, New York, 1998, chap. 2, p. 23. 